\title{
Cereal-based Fermented Foods for Enhanced Nutritional Attributes and Better Gut Health
}

\author{
Sangita Ganguly*, Latha Sabikhi and Ashish Kumar Singh \\ Dairy Technology Division, ICAR-National Dairy Research Institute, Karnal, Haryana, India \\ *Corresponding author: sangitandri@gmail.com
}

Received: 16-03-2021

Revised: $17-05-2021$

Accepted: 05-06-2021

\begin{abstract}
Cereal grains are known to be one of the most important dietary resources of nutrition in all over the world. Cereal are considered inferior in terms of nutritional and sensorial quality as compared to other foods. Several approaches have been recommended to enhance the nutritional qualities of cereals, however, the best one is fermentation. Fermentation, had been reported to improve sensory and nutritional quality of cereals. Generally, natural lactic fermentation of cereal results in a decrease in carbohydrates content together with increase in some amino acids and B-group vitamins. Further, fermentation results in reduction of antinutritional factors, leading to an increment in mineral availability and protein and starch digestibility. Traditionally, cereal based fermented foods are prepared from most commonly available cereals grains using natural fermentation involving mixed cultures of yeasts, bacteria and fungi. Several of them are used as side dish, breakfast and light meal, and main foods. The microbiology of several of this commonly consumed cereal based fermented foods is quite complex and unknown. Probiotic microorganisms are well known for their multipurpose health beneficial effects. Mostly dairy products had been used as substrate for probiotics for years. Recent times cereals are gaining popularity as a probiotic delivery vehicle due to their inherent attributes. Cereal grains can serve as a suitable carrier matrix of probiotic cultures by supporting the growth and survival of organisms. The current review focuses on some traditional cereal based fermented foods, potential of cereal grains to use as growth medium of probiotic cultures and finally, newly developed non-dairy probiotic food products.
\end{abstract}

Keywords: Fermentation, cereal, probiotic, fermented foods

Cereal grains are known to be one of the most important sources of dietary nutrition for global population all over the world. Although, it had been observed that the nutritional and sensorial quality of cereals and their products are sometimes lesser or poorer as compared to milk and dairy products. This may be due to cereals are having less protein and deficient in certain essential amino acids (lysine), poor digestibility and availability of nutrients due to the presence of several anti-nutritional factors (polyphenols, tannins and phytate) in addition to the coarse grain nature (Chavan and Kadam, 1989). Several approaches have been recommended to enhance the nutritional qualities of cereals like improvement in genetic factor and supplementation with amino acid protein concentrates or other protein-enriched resources like legumes or oil seeds. Apart from these, several processing techniques like cooking, sprouting, milling and fermentation are known to enhance the nutritional qualities of cereals, even though the best one is fermentation (MattilaSandholm, 1998).

How to cite this article: Ganguly, S., Sabikhi, L. and Singh, A.K. (2021) Cereal-based Fermented Foods for Enhanced Nutritional Attributes and Better Gut Health. Intl. J. Ferment. Food, 10(1): 01-12.

Source of Support: None; Conflict of Interest: None (9) 9 
Generally, natural cereal fermentation results a decrease in carbohydrates level together with some non-digestible poly and oligosaccharides. Formation of certain amino acids may take place with increment of B group vitamins. Further, fermentation offers suitable $\mathrm{pH}$ environments for enzymatic degradation of phytate presented in cereals forming complexes with minerals (iron, zinc, calcium, magnesium) and proteins. Similar decrease in phytate may boost the quantity of soluble minerals (iron, zinc and calcium) to several folds (Chavan and Kadam, 1989; Khetarpaul and Chauhan, 1990; Haard et al. 1999). It seems that impacts of fermentation on nutritional attributes of foods is variable, although the substantial improvements in nutrition is evident. During the corn meal fermentation the available lysine, methionine, and tryptophan concentration had increased (Nanson and Field, 1984). Similarly, fermentation significantly enhanced the protein quality and lysine level in maize, millet, sorghum, and other cereals (Hamad and Fields, 1979). On the other hand, it had been observed that the tryptophan level increased during uji preparation with a decrease in lysine content (McKay and Baldwin, 1990). Fermentation generally results to improvement in the shelf life and sensory quality of the final product. Cereal fermentations lead to formation of several volatile compounds, which contribute to improvement in aroma the products (Chavan and Kadam, 1989). The presence of volatiles like diacetyl, acetic acid and butyric acid converts fermented cereal products as more appealing.

Globally, Traditional fermented foods are prepared from most commonly available cereals grains like rice, wheat, corn or sorghum, etc.. Several of them are used as side dish, beverages, breakfast and light meal, whereas, some of them are utilized as main foods. The microbiology of several of these commonly consumed fermented foods is quite complex and unknown. Most of the products are produced by natural fermentation involving mixed cultures of yeasts, bacteria and fungi. Some microorganisms may grow in parallel manner, while others participate in a sequential fermentation following the growth of a dominant flora during the course. The common bacteria associated with fermention are species of bacillus, Leuconostoc, Lactobacillus, Streptococcus, Pediococcus; whereas, fungi genera are Penicillium, Aspergillus, Cladosporium; the common fermenting yeasts are species of Saccharomyces resulting in alcoholic fermentation (Steinkraus, 1998).

Effect on nutritional quality due to cereal fermentation

The effect of fermentation on physico-chemical properties of cereals are listed in Table 1.

Table 1: Changes in different physico-chemical parameter as a result of cereal fermentation

\begin{tabular}{|c|c|c|}
\hline Parameter & Change & References \\
\hline $\mathrm{pH}$ & Decrease & Au and Fields, 1981 \\
\hline Acidity & Increase & Au and Fields, 1981 \\
\hline Dry Matter & Decrease & Au and Fields, 1981 \\
\hline Carbohydrate & Decrease & $\begin{array}{l}\text { Kazanas and Fields, } \\
1981\end{array}$ \\
\hline Protein & Increase & $\begin{array}{l}\text { Hamad and Fields, } \\
1979\end{array}$ \\
\hline Amino acids & Increase & $\begin{array}{l}\text { Hamad and Fields, } \\
1979\end{array}$ \\
\hline Fat & $\begin{array}{l}\text { Slight increase to } \\
\text { no change }\end{array}$ & $\begin{array}{l}\text { Kazanas and Fields, } \\
\text { 1981; Chavan, } 1988\end{array}$ \\
\hline Minerals & $\begin{array}{l}\text { No significant } \\
\text { change }\end{array}$ & $\begin{array}{l}\text { Reddy and Salunkhe, } \\
1980\end{array}$ \\
\hline $\begin{array}{l}\text { Vitamins } \\
\text { (B-group) }\end{array}$ & Increase & $\begin{array}{l}\text { Murdock and Fields, } \\
1984\end{array}$ \\
\hline $\begin{array}{l}\text { Antinutritional } \\
\text { factors }\end{array}$ & Decrease & $\begin{array}{l}\text { Reddy and Salunkhe, } \\
1980\end{array}$ \\
\hline $\begin{array}{l}\text { Protein } \\
\text { digestibility }\end{array}$ & Improve & $\begin{array}{l}\text { Lorri and Svanberg, } \\
1993\end{array}$ \\
\hline Protein quality & Improve & $\begin{array}{l}\text { Hamad and Fields, } \\
1979\end{array}$ \\
\hline $\begin{array}{l}\text { Mineral } \\
\text { availability }\end{array}$ & Improve & $\begin{array}{l}\text { Khetarpaul and } \\
\text { Chauhan, } 1990\end{array}$ \\
\hline
\end{tabular}

The flora grows during fermentation depends on the various extrinsic and intrinsic factors like temperature, $\mathrm{pH}$, water activity, sugar and concentration of salt, and the composition of the substrate. The commonly consumed fermented foods in the eastern and western world, are known as lactic fermented products, but not characterised properly (Conway, 1996). Lactic acid fermentation provides the 
nutrition, acceptability, shelf life and safety to a wide range of cereal based fermented foods (Oyewole, 1997). The common processes follows cleaning of cereals followed by soaking in water for several days for natural lactic acid fermentation, which further associated with other operations like addition of salt, sugar, heat treatment, etc (Nout and Motarjemi, 1997). During this fermentation process endogenous grain carbohydrate serve as a source of energy for the lactic acid bacteria.

\section{Changes in protein content and quality}

Most of the studies indicate that yeast or natural fermentation results in slight improvement in protein content, which is mainly attributed to the loss in dry matter content mainly carbohydrates (Kazanas and Fields, 1981). Fermentation of corn meal with yeasts, (S. cerevisiae and C. tropicalis) resulted as increment in protein content from 7.6 to 8.9 and $8.4 \%$, respectively (Wang and Fields, 1978). However, the increase in protein content was attributed to losses in dry matter signifinicantly. Chavan et al. (1988) reported that the enhancement in protein content of sorghum; however, some researchers observed no change in protein content due to fermentation in cereals (Hamad and Fields, 1979). Although the quantitative changes are less, a significant qualitative improvements occur in proteins due to natural fermentation. The relative nutritional value (RNV) of maize increased from $65 \%$ to $81 \%$ as a result of germination and fermentation respectively, further fermentation of germinated maize flour resulted an increase in RNV to $87 \%$ (Lay and Fields, 1981). A significant increment in essential amino acids, particularly lysine, methionine, and tryptophan has been observed during fermentation (Hamad and Fields, 1979; Au and Fields, 1981). The available lysine content increased considerably in rice, wheat, oats, millet and corn during fermentation (Hamad and Fields, 1979). Further, in all cereals the increment in lysine content was higher at fermentation temperature of $37^{\circ} \mathrm{C}$ as compared to at 22 to $25^{\circ} \mathrm{C}$. Rice meal, when subjected to natural lactic fermentation with or without hulls resulted a substantial increase in nutritive value by enhancing isoleucine and lysine content (Tongnual and Fields, 1979). Fermentation of corn meal with food yeasts, improved the lysine content but decreased the methionine content in fermented meals. The percent RNV increased significantly due to this fermentation (Wang and Fields, 1978).

Bacterial fermentation of cereals and cereallegume blends resulted the highest enhancement in methionine content, whereas yeast fermentation caused a decrease in methionine. The main reason behind different changes in amino acids composition during bacterial and yeasty fermentation is the bacterial fermentations involve proteolytic activity, while yeasts mainly degrade carbohydrates. Both types of fermentation reportedly increased bioavailability of essential amino acids significantly, particularly lysine and methionine. The increment in percent RNV value is attributed to increase in availability of limiting amino acids of cereals and legumes (Hamad and Fields, 1979; Au and Fields, 1981). In animal feeding trials it was found that natural fermentation of pearl millet, sorghum, or finger millet did not enhance the PER significantly (Aliya and Geervani, 1981). The biological value (BV) and net protein utilization (NPU) of products of sorghum and finger millet improved significantly after fermentation but not those of pearl millet. It was further established that fermentation had minimal effect on overall protein quality of millets. Several researchers reported changes in PER of various foods as a result of fermentation as shown in Table 2.

\section{Changes in carbohydrates}

Carbohydrates mainly starch and soluble sugars are the principle fermenting component for lactic acid bacteria. Hence, degradation subsequent resulting a decrease in starch as well as total carbohydrate content are expected to occur during natural fermentation of cereals. Kazanas and Field (1981) and Chavan (1988) reported a decrease in the starch and fibre contents and increase in the reducing sugars content during natural fermentation of sorghum. The availability of starch increased significant level during natural fermentation (Kazanas and Fields, 1981). The decrease 
Table 2: Changes in Protein Efficiency Ratio (PER) of protein as a result of food fermentation

\begin{tabular}{|c|c|c|c|c|c|}
\hline \multirow{2}{*}{ Product } & \multirow{2}{*}{ Ingredients } & \multicolumn{2}{|c|}{ PER } & \multirow{2}{*}{$\triangle$ PER } & \multirow{2}{*}{ References } \\
\hline & & Before & After & & \\
\hline \multirow{6}{*}{ 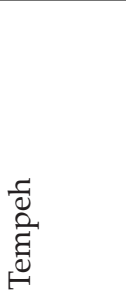 } & Chickpea & 1.95 & 2.11 & 0.16 & Kao and Robinson (1978) \\
\hline & Horsebean & 0.89 & 1.51 & 0.62 & Kao and Robinson (1978) \\
\hline & Soybean & 2.17 & 2.27 & 0.10 & Wang et al. (1968) \\
\hline & Soybean & 1.77 & 2.03 & 0.26 & Kao and Robinson (1978) \\
\hline & Wheat & 1.28 & 1.71 & 0.43 & Wang et al. (1968) \\
\hline & Wheat/soybean (1:1) & 2.49 & 2.79 & 0.30 & Wang et al. (1968) \\
\hline \multirow{2}{*}{$\ddot{z}$} & (Blackgram/rice, 4:1) & 2.28 & 2.55 & 0.27 & Rao (1961) \\
\hline & (Blackgram/rice, 4:1) & 1.50 & 2.00 & 0.50 & Rajalakshmi and Vanaja (1967) \\
\hline
\end{tabular}

in fibre content during fermentation might be due to partial solubilisation of cellulose and hemicellulosic by enzymes from microbes (Beuchat et al. 1975).

\section{Changes in lipids}

The report depicting quantitative changes in lipids of cereals during natural lactic or fungal fermentations are limited. Most studies regarding natural fermentation of cereals and legumes with bacteria or yeasts have described changes in proteins, amino acids and B-group vitamins. This is because the fact that cereals are low in fats. But this type of investigations are important, particularly relatively oil-rich cereals like corn and pearl millet. Kazanas and Fields (1981) did not observe a significant change in crude fat content of sorghum during natural lactic fermentation. However, Chavan (1988) reported a slight increase in crude fat content of sorghum and sorghum plus green gram blend due to fermentation process. Actually, fat content is pretty small in most cereals and legumes and their availability is not a nutritional concern in these food grains. The changes in lipid portion in cereals during fermentation may impact the functional and sensory qualities of fermented products.

\section{Changes in vitamins}

The vitamin content, especially B-group vitamins has been reported to increase during natural fermentation of cereals, although considerable variation were found in different reports. The thiamine, riboflavin, and niacin contents increased significantly during natural fermentation of pearl millet (Stott et al. 1963), rice (Tongnual and Fields, 1979) and sorghum (Kazanas and Fields, 1981). Murdock and Fields (1984) reported a significant increase in the vitamin $B_{12}$ folacin, riboflavin, and pantothenic acid contents during natural fermentation of corn meal. No appreciable changes in biotin, pyridoxine, thiamine, choline and niacin contents were observed. A significant increase in riboflavin content and a significant decrease in niacin and thiamin content was observed during fermentation rice meal (Tongnual and Fields, 1979). A slight increase in thiamine content, a greater increase in niacin content, whereas no appreciable change in riboflavin content was observed during fermentation of sorghum meal for kisra preparation (El-Tinay et al. 1979). Most of the studies reported changes of B-group vitamins during natural fermentation of cereals and cereals-legumes blends, which are influenced by several factors like raw materials nature, type and level of microflora, temperature, fermentation duration, and methods of determination of these vitamins. The mechanism of such changes in vitamin content is not fully explained and needs to be further investigated.

\section{Changes in minerals}

Cereals are good source of dietary minerals, but availability of minerals are important nutritional issue. Kazans and Fields (1981) did not find any change in total ash content of sorghum during 
fermentation. The changes in individual mineral elements during fermentation of rice, black gram, and rice plus black gram blend were studied by Reddy and Salunkhe (1980). No apparent changes were noted in the concentrations of minerals (calcium, magnesium, total phosphorus, zinc and iron). Several workers observed enhancement in availability of minerals due to fermentation. Fermentation was observed more effective in increasing $\mathrm{Ca}, \mathrm{P}$ and $\mathrm{Fe}$ bioavailability in finger millet (Sripriya et al. 1996). Similarly rabadi fermentation of barley flour at different temperature and time resulted a significant increase in extractability of minerals. Longer periods and higher temperature of fermentation resulted in an increased $\mathrm{HCl}$-extractability of minerals (Gupta et al. 1992). Similar increment in mineral extractability was observed due to natural fermentation of precooked pearl millet flour (Khetarpaul and Chauhan, 1990) and rabadi fermentation of freshly ground wheat flour-buttermilk mixture (Gupta et al. 1991). Similarly during rabadi preparation from pearl millet flour/buttermilk mixture at different temperature and periods of fermentation, fermentation at all temperatures decreased phytate $\mathrm{P}$, increased nonphytate $\mathrm{P}$ and $\mathrm{HCl}$ extractability of minerals; the increased extractability was observed with an increasing periods of fermentation (Dhankher and Chauhan, 1989). Probiotic fermentation of food blends consisting of germinated pearl millet flour, whey powder and tomato pulp caused a significant $(\mathrm{P}<0.05)$ improvement in availability of $\mathrm{Ca}$, $\mathrm{Fe}$ and $\mathrm{Zn}$ (Arora et al. 2011). The probable reason for increment in mineral availability as a result of fermentation may be decrease in antinutrients, mainly phytic acid content, as a negative correlation have been detected with HCl-extractability of minerals (Gupta et al. 1992; Gupta et al. 1991).

\section{Cereal based fermented products}

\section{Idli}

Idli is apopular breakfast item in India. It is a low calorie, starch enriched nutritious food. It comprises about $3.4 \%$ protein, $20.3 \%$ carbohydrate and $70 \%$ moisture (Teniola and Odunfa, 2001). Idli is prepared from a fermented thick suspension made of a blend of rice and dehauled black gram by application of steaming (Nagaraju and Manohar, 2000). The lactic acid bacteria Lactobacillus fermenti, Leuconostoc mesenteroids, Streptococcus faecalis, Pediococcus cerevisiae and Lactobacillus lactis have been found to be liable for the fermentation process, although L. mesenteroids and S. faecalis are the major flora considered for acid production in idli batter. The yeasts like Geotrichum candidum and Torulopsis candida have also been found in fermented idli batter (Chavan and Kadam, 1989). Fermentation of idli batter has been reported to have a enhancing effect in essential amino acids and in the reduction of antinutrients (Steinkraus et al. 1993).

\section{Dosa}

The dosa batter is very similar to idli batter and the microbiological, physical, biochemical and nutritive changes of dosa batter during fermentation are quite similar to idli (Purushothamman et al. 1993). The product is prepared by spreading of fermented suspension on a flat heated plate with a little oil or fat (Battacharya and Bhat, 1997).

\section{Kenkey}

Kenkey is a fermented maize product consumed in Ghana. Kenkey is made by using two methods, firstly, the maize grains are water-soaked at room temperature for 1-2 days, followed by draining of water and wet-milling of grains and the meal is kept for a spontaneous or solid state fermentation to produce a stiff dough. In the second method, the maize meal is combined with a large volume of water and strained followed by the overnight fermentation of mixture. The wet mash after removing the water is cooked to make porridge (McKay and Baldwin, 1990). The fermentation is mainly governed by array of lactic acid bacteria, like Lactobacillus fermentum and L. reuteri followed by presence of yeasts and moulds, that contribute towards flavour development.

\section{Pozol}

Pozol, mainly consumed in South-eastern Mexico, is a fermented maize product in the form of balls of 
various sizes and shapes. Maize grains are boiled in limewater and grounded coarsely, the resulting dough is subjected to kneading to form a ball of compact mass which is wrapped in banana leaves and left for fermentation at ambient temperature. A complex microbial community (Lactococcus lactis, Lactobacillus plantarum, Lactobacillus casei, Lactobacillus delbruekii and Clostridium sp., etc.) incorporated mainly during the grinding process takes part in the fermentation of the dough (Nanson and Field, 1984).

\section{Kishk}

Kishk is an important food of Middle East and mainly prepared by fermentation of milk-wheat mixtures. Kishk is usually made by addition of strained yoghurt to cracked and bran-free parboiled wheat termed as bulgur followed by fermenting the mix at ambient temperature for different time intervals. The wheat grains are boiled to make soft, dried, milled and sieved to remove the bran. Milk is separately fermented by lactic bacteria in a container, concentrated and mixed with the moistened wheat flour. The resultant paste is dried to around $10-13 \%$ moisture content and then made to powder by grinding and the product is stored in the form of dried balls having brown colour with a rough surface and hard texture. The microorganisms associated with fermentation includes Lactobacillus casei, Lactobacillus plantarum, Lactobacillus brevis, Bacillus subtilis and yeasts (Beuchat, 1983; Chavan and Kadam, 1989). Kishk is a nutritious food rich in B vitamins having good preservation quality..

\section{Tarhana}

Tarhana (Trahanas) is produced by blending wheat flour, yoghurt, yeast and several cooked vegetables and spices (tomatoes, onions, salt, mint, paprika) followed by fermentation of the substrate for 1-7 days. The fermentation process and type of product is very similar to kishk. The major fermenting organisms are Streptococcus thermophilus and Lactobacillus bulgaricus. The fermented matter is dried and stored in the form of biscuits (Campbell-platt, 1994). Tarhana has an acidic taste and yeasty flavour and is a good source of nutrients like protein and vitamins. The addition of cereal protein with dairy protein leads to improvement in nutritional quality. The low $\mathrm{pH}$ (3.8-4.2) and low moisture content (6-9\%) make the product less suitable for pathogens and spoilage organisms. The tarhana powder can be stored for long time (1-2 years) without any sign of deterioration.

\section{Ogi}

Ogi is considered as the most important weaning food for infants in West. Ogi is a fermented cereal guel processed from maize, although sorghum and millet are also sometimes used for fermentation. Lactic acid bacteria, yeasts and molds are liable for the fermentation. The predominant species involved is Lactobacillus plantarum and other organism like Corynebacterium sp., sometimes yeasts of Saccharomyces and Candida species are responsible for flavour development (Caplice and Fitzgerald, 1999). However, about $20-50 \%$ of the nutrients available in the original cereals are lost during production of ogi. Substantial losses of lysine and tryptophan have been reported. The colour of ogi varies on the basis of cereal used for its preparation: cream-white for maize, reddish brown for sorghum and dirty grey for millet.

\section{Injera}

Injera is undisputed national food of Ethiopia (Oda et al. 1983). It can be produced from different cereals like sorghum, tef, corn, finger millet and barley etc. Although, tef is the major cereal and sorghum second most preferred ingredient for making injera. The grains are dehulled and milled into flour, the flour is mixed with water to form a dough followed by addition of starter. The dough is subjected to fermentation for 2 to 3 days. After fermentation the dough is converted into a thick batter and poured onto a lightly oiled pan, which is then covered and steamed (Parker et al. 1989). The microbiota involved in fermentation are mainly yeasts (Beuchat, 1983). The major quality attribute of a good product is its slightly sour flavour. The product contains over $50 \%$ moisture, $4.8 \%$ protein, and is a good source of calcium and iron (Zegeye, 1997). 


\section{Mahewu}

Mahewu, a non-alcoholic beverage consumed in Africa and Arabian Gulf countries, is sour in nature and generally prepared from corn meal (Chavan \& Kadam 1989). It is made from maize porridge, which is mixed with water and sorghum, millet malt or wheat flour and subjected to fermentation (Odunfa et al. 2001). The fermentation is held by natural flora of the malt at ambient temperature (Gadaga et al. 1999). The predominant flora of the fermentation belongs to Lactococcus lactis sub sp. Lactis (Steinkraus et al. 1993).

\section{Boza}

Boza is a non-alcoholic beverage consumed in Albania, Bulgaria, Romania and Turkey and characterized by a light to dark colour, sweet, slightly sharp and slightly sour in taste. It is made of wheat rye, millet, maize and other cereals combined with sugar and sweetner (Hancioglu and Karapinar, 1997). Boza mainly consists of lactic acid bacteria and yeasts in the ratio of 2.4 (Gotcheva et al. 2000). The lactic culture identified mainly of Lactobacillus plantarum, $\mathrm{Lb}$ acidophilus, Lb fermentum, Leuconostoc raffinolactis, Ln mesenteroids and Ln brevis and the yeasts isolated consist of Saccharomyces cerevisiae, Candida tropicalis, Geotricum candidum etc. (Gotcheva et al. 2000). A significant increase in glucose level is observed during Boza formation, with a decrease in $\mathrm{pH}$, viscosity, free amino nitrogen content and dry matter.

\section{Yosa}

Yosa is a snack type food prepared from oat bran which cooked in water and fermented with lactic organism and Bifidobacteria. After fermentation, the matter is subjected to flavouring with sucrose or fructose and fruit jam. The product is mainly consumed in Finland and other Scandinavian countries. Though, the product has a similar texture and flavour like yoghurt but it is completely free from milk (Toufeili et al. 1997). It is a vegetarian diet which is lactose-free, low in fat and having $\beta$-glucan in it. Yasa is a healthy food as it contains oat fibre and probiotic which is beneficial for intestinal health (Toufeili et al. 1997). Oat fibre is also a good source of $\beta$-glucan, which has been reported to reduce cholesterol and helpful in heart disease.

\subsection{PROBIOTIC}

The concept of probiotics for disease and health management is not new. However, recently, there has been a renewed interest for use of probiotics as biotherapeutic agents due to consciousness of consumers. The Greek meaning of the word probiotic is 'for life'. Fuller (1989) provided a revised definition of probiotic as a live microbial feed supplement beneficially affecting the host by improving its intestinal microbial balance. Probiotics can be used for modulation of immunity, lowering blood cholesterol level, management of rheumatoid arthritis, prevention of cancer, manage lactose intolerance, and prevention or reduction of diarrhoea, constipation, urinary tract infections (UTI) and candidiasis (Reid, 1999). The suggestive dose of probiotic organisms as suggested is about 6 to $8 \mathrm{Log}$ cfu per $\mathrm{g}$ or $\mathrm{ml}$ of a product to deliver health beneficial effects (Ganguly et al. 2019). Probiotics can be bacteria, molds or yeasts, though the most common probiotics used are bacteria, mainly the lactobacilli and bifidabacteria.

\section{Cereals as substrate of probiotic}

Most probiotic food products in the markets worldwide are milk-based, and very limited attempts have been made to utilize other substrates such as cereals and combination of milk and cereals for probiotic product formulation. Traditionally fermented milks like yogurt was considered as major matrix for probiotic organisms, but in recently probiotic is being incorporated into a range of food items like beverages, powder, ice cream etc. (Shah, 2001). Increasingly, whole grain is turning out to be one of the chosen substrate as delivery vehicle of probiotic organisms. This is primarily because the formulation of cereal based probiotic products offers consumers a dual benefits of bioactive components of whole grain and probiotic (Marquart and Cohen, 2005). This enhances the nutritive value of the product and also appeals to the consumers. The possible application of cereal components in probiotic food 
Ganguly et al.

Table 3: Selected cereal based probiotic fermented foods

\begin{tabular}{lll}
\hline Category & Product & Reference \\
\hline Rice & Rice-Based Fermented Beverage & Giri et al. 2018 \\
& Brown-rice based probiotic beverage & Ndife et al. 2019 \\
& Rice- yogurt & Wongkhalaung and Boonyaratanakornkit (2000) \\
\hline Maize & Maize- beverage (Pozol) & Wacher et al. (2000) \\
& Mahewu (fermented maize beverage) & McMaste et al. (2005) \\
\hline Oat & Oat-based products & Martensson et al. (2002) \\
& Yosa (oat-bran pudding) & Blandino et al. (2003) \\
& Oat-based drink & Angelov et al. (2006) \\
& Malt-based drink & Kedia et al. (2007) \\
\hline Millet & Millet-based Probiotic Fermented Food & Di Stefano et al. (2017) \\
& Millet or sorghum flour fermented probiotic & Muyanja et al. (2003) \\
& beverage (Bushera) & \\
\hline Other/ Mix & Boza (Probiotic fermentation) & Arslan-Tontul \& Erbas (2020) \\
cereals & Cereal-based puddings & Helland and others (2004) \\
& Starch-saccharified probiotic drink & Oi and Kitabatake (2003) \\
& Probiotic cassava-flour product & Molin (2001) \\
\hline
\end{tabular}

formulations could be as a fermentable substrates for starter cultures or encapsulating material. Numerous cereal-based prebiotics and probiotic foods have been launched recently, particularly in the European market. Some of the examples can be indicated as cereal bars (CornyActiv ${ }^{\circledR}$ ) in Germany, probiotic flakes (Muesli ${ }^{\circledR}$ ) in Portugal, whole wheat breakfast cereals (Weetaflakes $\AA$ ) in France and snack bar (Goodness ${ }^{\circledR}$ ) in UK (Dornblaser, 2007).

\section{Effect of cereal substrate on growth of probiotics}

Probiotic foods are mainly standardized based on the viable culture concentration and a minimum cell concentration of approximately 7-8 Log cfu cells per $\mathrm{g}$ or $\mathrm{ml}$ at the point of consumption is thought as useful (Gomes and Malcata, 1999). High growth rates resulting in reduced fermentation times supporting the viability of the definite strain and prevention of growth of unwanted organism existing in the raw material (Marklinder and Lonner, 1992), which generally results in formation of off-flavours and other undesirable product quality (Svensson, 1999). Thus, the adaptability of specific probiotic strain in a particular substrate is an important selection criterion for a specific strain (Oberman and Libudzisz, 1998).

Lactobacilli and bifidobacteria have complicated nutritional needs which differ from species to species. The principle carbohydrate ingredients of cereal grains are starch, water-soluble or insoluble components of dietary fibre, and several free sugars, like glucose, glycerol, stachyose, sucrose, etc. at various level. Information regarding the impacts of cereal composition on the growth kinetics of probiotic microorganisms is less reported. Marklinder and Lonner (1992) reported oats in general as a suitable medium for probiotic growth, irrespective of species and strains. Among all tested strains, L. acidophilus demonstrated lowest viable cell counts in the final product, due to probably its higher nutrients requirements (Morishita et al. 1981). Charalampopoulos et al. (2002) investigated growth kinetics of four hypothetically probiotic strains $(L$. fermentum, L. reuteri, L. acidophilus and L. plantarum) using malt, barley, and wheat extracts without the addition of any supplements. It was found that malt medium supported better cell growth than other 
substrate due to presence of higher amounts of sugars and free amino nitrogen. It must be considered that each strain exhibited a specific preference for one or more sugars. L. plantarum demonstrated the highest cell population due its ability to bear low $\mathrm{pH}$ (Giraud et al. 1998).

\section{Survival of probiotics in the presence of cereal substrate}

The ability of probiotic organisms to endure in the acidic atmosphere of the final fermented product (in vitro) as well as the adverse environment of gastrointestinal tract (in vivo) is an important criteria for selection. The survival of the probiotic bacteria in vitro might be affected by metabolites formed during fermentation like lactic acid, acetic acid, etc. (Saarela et al. 2000). Hence, the final $\mathrm{pH}$ of product and concentrations of lactic acid and acetic acid in fermented product have to be studied in relation to maximum survival of probiotic organism during storage. Survival of probiotic strains during gastric transit is also influenced by food delivery medium. The buffering capacity and the $\mathrm{pH}$ of the carrier medium are of prime importance, since food formulations having high buffering capacity would improve the survival of the probiotic strain (Zarate et al. 2000). Additionly, it has been observed that wheat, malt and barley extracts have a considerable protective effect on the survival of probiotic organisms under acidic conditions mimicking the stomach, which may be due to the presence of soluble sugars of cereals and the free amino nitrogen content to the lesser extent (Charalampopoulos et al. 2003). Table 5. depicts the recently developed selected non-dairy probiotic products.

\section{CEREAL BASED FERMENTED MILK BEVERAGE}

Gupta et al. (1992) prepared rabadi from barley flour and sour buttermilk, by mixing autoclaved barley flour with fermented buttermilk @ 5\% by weight. The mixtures were stirred sufficiently and again fermented at 30,35 and $40^{\circ} \mathrm{C}$ for $6,12,18,24$ and $48 \mathrm{~h}$ followed by salting. The product fermented at $35^{\circ} \mathrm{C} / 18 \mathrm{~h}$ had highest overall acceptability.

The technology for the preparation of cereal based fermented milk beverage using three different cereals, viz. wheat (Girish, 2006), pearl millet (Modha and Pal, 2011) and sorghum (Pintu, 2006) were developed at NDRI (Karnal), India. The germinated cereal flour was mixed with milk (standardized certain ratio of fat and SNF), pasteurized, cooled, inoculated with suitable starter culture and incubated for suitable time to obtain acceptable $(0.9 \%$ to $1 \%)$ lactic acidity. The curd thus obtained is mixed with pasteurized water containing stabilizers, spices and salt. The product had a keeping quality of 7 days at refrigeration temperature $\left(7-8^{\circ} \mathrm{C}\right)$.

A composite substrate was prepared using whey, skim milk and cereals (pearl millet and barley) and was found to support growth of a probiotic organism Lactobacillus acidophilus (NCDC-13) which is a dairy isolate (Ganguly and Sabikhi 2012) and enhanced nutritional attributes of the substrate by enhancing digestibility of protein and starch and reducing antinutrients (phytic acid and polyphenol) content (Ganguly et al. 2013). Further the probiotic substrate was converted into sour-spicy beverage and found effective in controlling shigella induced pathogenicity in muring model (Ganguly et al. 2019).

A milk-barley based probiotic beverage was prepared using Lactobacillus plantarum and co-culture Streptococcus thermophilus. The beverage had high (8.59 $\log \mathrm{cfu} / \mathrm{ml}$ ) probiotic (Lactobacillus plantarum) count and $\beta$-glucan content $(0.144 \mathrm{~g} / 100 \mathrm{~g})$. The product had detected with ABTS radical scavenging activity of $0.40 \pm 0.01 \mathrm{mg}$ TEAC/mL (Ahuja et al. 2017).

\section{CONCLUSION}

Several traditional cereals based fermented food products are available in worldwide and have the potential to convert as probiotic products. Lack of information about these traditional cereal based fermented products are main constraints and studies are needed in this arena to develop novel probiotic cereal products for combining health beneficial attributes of probiotic and cereals effectively. The most typical and traditional matrices for probiotic cultures are fermented dairy products. Inspite of the fact that probiotic cultures demand variety of 
nutrients, cereal can serve as potential substrate for growth of probiotic organisms.

\section{REFERENCES}

Ahuja, K.K., Singh, A.K., Bala, K., Arora, S. and Sabikhi, L. 2017. Optimisation of the formulation for barley-milk composite-based fermented drink. International Journal of Dairy Technology, 70(2): 237-244.

Aliya, S. and Geervani, P. 1981. An assessment of protein quality and vitamin B content of commonly used fermented products of legumes and millets. Journal of the Science of Food and Agriculture, 32(8): 837-842.

Angelov, A., Gotcheva, V., Kuncheva, R. and Hristozova, T. 2006. Development of a new oat-based probiotic drink. International Journal of Food Microbiology, 112(1): 75-80.

Au, P.M. and Fields, M.L. 1981. Nutritive quality of fermented sorghum. Journal of Food Science, 46(2): 652-654.

Battacharya S. and Bhat K.K. 1997. Steady shear rheology of rice-blackgram suspensions and suitability of rheological models. Journal of Food Engineering, 32(3): 241-250.

Beuchat, L.R. 1983. Indigenous fermented foods. G. Reed (Ed.). In: 'Biotechnology. Food and feed production with microorganisms'. Weinheim: Verlag Chemie.

Beuchat, L.R., Young, C.T. and Cherry, J.P. 1975. Electrophoretic patterns and free amino acid composition of peanut meal fermented with fungi. Canadian Institute of Food Science and Technology Journal, 8(1): 40-45.

Blandino, A., Al-Aseeri, M.E., Pandiella, S.S., Cantero, D. and Webb, C. 2003. Cereal-based fermented foods and beverages. Food Research International, 36(6): 527-543.

Campbell-platt G. 1994. Fermented foods- a world perspective. Food Research International, 27(3): 253-257.

Caplice, E. and Fitzgerald, G.F. 1999. Food fermentations: role of microorganisms in food production and preservation. International Journal of Food Microbiology, 50(1-2): 131-149.

Charalampopoulos, D., Pandiella, S.S. and Webb, C. 2002. Growth studies of potential probiotic lactic acid bacteria in cereal-based substrates. Journal of Applied Microbiology, 92(5): 851-859.

Charalampopoulos, D., Pandiella, S.S. and Webb, C. 2003. Evaluation of the effect of malt, wheat and barley extracts on the viability of potentially probiotic lactic acid bacteria under acidic conditions. International Journal of Food Microbiology, 82(2): 133- 141.

Chavan U.D., Chavan J.K. and Kadam S.S. 1988. Effect of fermentation on soluble proteins and in vitro protein digestibility of sorghum, green gram, and sorghum green gram blends. Journal Food Science, 53(5): 1574-1575.

Chavan, J.K. 1988. Malting and fermentation of sorghum and sorghum-legume blends for improvement in nutritional and bhakari making quality. Final report of ICAR ad-hoc Project. Mahatma Phule Agricultural University, Rahuri, India.

Chavan, J.K. and Khadam, S.S. 1989. Nutritional improvement of cereals by fermentation. Critical Reviews of Food Science and Nutrition, 28(5): 348-400.

Conway, P.L. 1996. Selection criteria for probiotics microorganisms. Asia Pacific Journal of Clinical Nutrition, 5: 10-14.

Dhankher, N. and Chauhan, B.M. 1989. Effect of fermentation on $\mathrm{HCl}$ extractability of minerals in Rabadi- an indigenous fermented food of India. Journal of the Science of Food and Agriculture, 49(4): 467-472.

Di Stefano, E., White, J., Seney, S., Hekmat, S., McDowell, T., Sumarah, M. and Reid, G. 2017. A Novel Millet-Based Probiotic Fermented Food for the Developing World. Nutrients, 9(5): 529.

Dornblaser, L. 2007. Probiotics and Prebiotics: What in the World is Going On? Cereal Foods World, 52(1): 20-21.

El-Tinay, A.H., Abdel Gadir, A.M. and El-Hidai, M. 1979. Sorghum fermented kisra bread. 1. Nutritive value of kisra. Journal of Science of Food and Agriculture, 30(9): 859-863.

Fuller, R. 1989. Probiotics in man and animals. Journal of Applied Bacteriology, 66(5): 365-378.

Gadaga, T.H., Mutukumira, A.N, Narvhus, J.A. and Feresu, S.B. 1999. A review of traditional fermented foods and beverages of Zimbabwe. International Journal of Food Microbiology, 53(1): 1-11.

Ganguly, S. and Sabikhi, L. 2012. Fermentation dynamics of probiotic Lactobacillus acidophilus NCDC-13 in a composite dairy-cereal substrate. International Journal of Fermented Foods, 1(1): 33-46.

Ganguly, S., Kumar, S.M.H., Singh, A.K. and Sabikhi, L. 2013. Effect of fermentation by probiotic Lactobacillus acidophilus NCDC-13 on nutritional profile of a dairy-cereal based composite substrate. Journal of Food \& Nutritional Disorders. Special Issue on 'The Role of Prebiotics and Probiotics in Human Health' S1-002, doi: 10.4172/2324-9323.S1-002.

Ganguly, S., Sabikhi, L., and Singh, A.K. 2019. Effect of whey-pearl millet-barley based probiotic beverage on Shigella-induced pathogenicity in murine model. Journal of Functional Foods, 54: 498-505.

Giraud, E., Champailler, A., Moulard, S. and Raimbault, M. 1998. Development of a miniaturized selective counting strategy of lactic acid bacteria for evaluation of mixed starter in a model cassava fermentation. Journal of Applied Microbiology, 84(3): 444-450.

Giri, S.S., Sen, S.S., Saha, S., Sukumaran, V. and Park, S.C. 2018. Use of a Potential Probiotic, Lactobacillus plantarum L7, for the Preparation of a Rice-Based Fermented Beverage. Frontiers in Microbiology, 9: 473. 
Girish, L. 2006. Development of a rabadi-like fermented beverage from wheat and milk solids. M.Sc. Thesis. National Dairy Research Institute (Deemed University), Karnal. (Haryana), India.

Gomes, A.M.P. and Malcata F.X. 1999. Bifidobacterium ssp. and Lactobacillus acidophilus: biological, 'biochemical, technological and therapeutical properties relevant for use as probiotics. Trends in Food Science and Technology, 10(4): 139-157.

Gotcheva, V., Pandiella, S.S., Angelov, A., Roshkova, Z.G. and Webb, C. 2000. Microflora identification of Bulgarian cerealbased fermented beverage boza. Process Biochemistry, 36(12): $127-130$.

Gupta, M., Khetarpaul, N. and Chauhan, B.M. 1991. Effect of Rabadi fermentation on $\mathrm{HCl}$-extractability of minerals of wheat. Food Chemistry, 42(1): 111-117.

Gupta, M., Khetarpual, N. and Chauhan, B.M. 1992. Preparation nutritional value and acceptability of barley rabadi- an indigenous fermented food of India. Plant Foods for Human Nutrition, 42(4): 351-358.

Haard, N.F., Odunfa, S.A., Lee, C.H., Quintero-Ramirez, R., Lorence-Quinones, A. and Wacher-Radarte, C. 1999. Fermented cereals: A global perspective. FAO Agricultural Services Bulletin No. 138.

Hamad A.M. and Fields M.L. 1979. Evaluation of protein quality and available lysine of germinated \& fermented cereals. Journal of Food Science, 44(2): 456-459.

Hancioglu, O. and Karapinar, M. 1997. Microflora of boza, a traditional fermented Turkish beverage. International Journal of Food Microbiology, 35(3): 271-274.

Helland, M.H., Wciklund, T., Narvhus, J.A. 2004. Growth and metabolism of selected strains of probiotic bacteria in milk- and water-based cereal puddings. International Dairy Journal, 14(11): 957-965.

Kao, C. and Robinson, R.J. 1978. Nutritional aspect of fermented foods from chickpea, horsebean and soybeans. Cereal Chemistry, 55(4): 512-517.

Kazanas, N. and Fields, M.L. 1981. Nutritional improvement of sorghum by fermentation. Journal of Food Science, 46(3): 819-821.

Kedia, G., Wang, R., Patel, H. and Pandiella, S.S. 2007. Used of mixed cultures for the fermentation of cereal-based substrates with potential probiotic properties. Process Biochemistry, 42(1): 65-70.

Khetarpaul, N. and Chauhan, B.M. 1990. Improvement in $\mathrm{HCl}$-extractability of minerals from pearl millet by natural fermentation. Food Chemistry, 37(1): 69-75.

Lay, M.M.G. and Fields, M.L. 1981. Nutritive value of germinated corn and corn fermented after germination. Journal of Food Science, 46(4): 1069-1073.
Lorri, W. and Svanberg, U. 1993. Lactic-fermented cereal gruels with improved in vitro digestibility. International Journal Food Science and Nutrition, 44(1): 29-36.

Marklinder, I. and Lonner, C. 1992. Fermentation properties of intestinal strains of Lactobacillus, of sour dough and of a yoghurt starter culture in an oat-based nutritive solution. Food Microbiology, 9(3): 197-205.

Marquart, L. and Cohen, E. 2005. Increasing Whole Grain Consumption. Food Technology, 59(12): 24-31.

Martensson, O., Oste, R. and Holst, O. 2002a. The effect of yoghurt culture on the survival of probiotic bacteria in oatbased, non-dairy products. Food Research International, 35: 775-84.

Mattila-Sandholm, T. 1998. VTT on lactic acid bacteria. VTT Symposium. VTT Infomation Service, Finland. 156: 1-10.

McKay, L.L. and Baldwin, K.A. 1990. Applications for biotechnology: present and future improvements in lactic acid bacteria. FEMS Microbiology Letters, 87(1-2): 3-14.

McMaste, L.D., Kokott, S.A., Reid, S.J., Abratt, V.R. 2005. Use of traditional African fermented beverages as delivery vehicles for Bifidobacterium lactis DSM 10140. International Journal of Food Microbiology, 102(2): 231-237.

Modha, H. and Pal, D. 2011. Optimization of Rabadi-like fermented milk beverage using pearl millet. Journal of Food Science and Technology, 48(2): 190-196.

Molin, G. 2001. Probiotics in foods not containing milk or milk constituents, with special reference to Lactobacillus plantarum 299v. American J. Cli. Nutr., 73(2): 380S-385S.

Morishita, T., Deguchi, Y., Yajima, M., Sakurai, T. And Yura, T. 1981. Multiple nutritional requirements of lactobacilli: genetic lesions affecting amino acid biosynthetic pathways. Journal of Bacteriology, 148(1): 64-71.

Murdock, F.A. and Fields, M.L. 1984. B-vitamin content of natural lactic fermented cornmeal. Journal of Food Science, 49(2): 373-375.

Muyanja, C.M., Narvhus, J.A., Treimo J. and Langsrud T. 2003. Isolation, characterisation and identification of lactic acid bacteria from bushera: a Ugandan traditional fermented beverage. Int. J. Food Microbioliology, 80(3): 201-210.

Nagaraju, V.D. and Manohar, B. 2000. Rheology and particle size changes during idli fermentation. Journal of Food Engineering, 43(3): 167-171.

Nanson, N.J. and Field, M.L. 1984. Influence of temperature on the nutritive value of lactic acid fermented cornmeal. Journal of Food Science, 49(3): 958-959.

Ndife, J., Linus-Chibuezeh, A., Ezeocha, C.V., Ojinnaka, C.M. 2019. Development and Evaluation of a Non-Dairy Probiotic Beverage from Brown Rice (Oryza sativia). Journal of Food Processing Technology, 10: 806.

Nout, M.J.R. and Motarjemi, Y. 1997. Assessment of fermentation as a household technology for improving 
food safety: a joint FAO/ WHO workshop. Food Control, 8(5-6): 221-226.

Oberman, H. and Libudzisz, Z. 1998. Fermented milks. Wood, B.J.B. (Ed), In: Microbiology of Fermented Foods, Vol.1. Blackie Academic and Professional, London, UK., pp. 308349.

Oda, M., Hasegawa, H., Komatsu, S., Kambe, M. and Tsuchiya, F. 1983. Anti-tumour polysaccharide from Lactobacillus sp. Agricultural and Biological Chemistry, 47(7): 1623-1625.

Odunfa, S.A., Adeniran, S.A., Teniola, O.D. and Nordstrom, J. 2001. Evaluation of lysine and methionine production in some lactobacilli and yeasts from ogi. International Journal of Food Microbiology, 63(1): 159-163.

Oi, Y. and Kitabatake, N. 2003. Chemical composition of an East African traditional beverage, togwa. Journal of Agriculture and Food Chemistry, 51(24): 7024-7028.

Oyewole, O.B. 1997. Lactic fermented foods in Africa and their benefits. Food Control, 8(5-6): 289-297.

Parker, M.L., Umeta, M. and Faulks, R.M. 1989. The contribution of flour components to structure of injera, an Ethiopian fermented bread made from tef (Eragrostis tef). Journal of Cereal Science, 10(2): 93-104.

Pintu, R.K. 2006. Development of rabadi-like fermented beverage from sorghum and milk solids. M.Sc. Thesis. National Dairy Research Institute (Deemed University), Karnal. (Haryana), India.

Purushothaman, D., Dhanapal, N. and Rangaswami, G. 1993. Indian idli, dosa, dhokla, khaman, and related fermentations. K.H. Steinkraus (Ed.). In: 'Handbook of indigenous fermented foods' . New York: Marcel Dekker, pp. 149-165.

Rajalakshmi, R. and Vanaja, K. 1967. Chemical and Biological evaluation of the effects of fermentation on the nutritive value of foods prepared from rice and grams. British Journal of Nutrition, 21(2): 467-473.

Rao, M.V.R. 1961. Some observations on fermented foods, in Progress in meeting Protein Needs of Infants and Preschool Children, Publ. No. 843, National Academy of Sciences, National Research Council, Washington, D.C., 291.

Reddy, N.R. and Salunkhe, D.K. 1980. Changes in oligosaccharides during germination and cooking of black gram/ rice blend. Cereal Chemistry, 57(5): 356-360.

Reid, G. 1999. The Scientific Basis for Probiotic Strains of Lactobacillus. Applied and Environmental Microbiology, 65(9): 3763-3766.

Saarela, M., Mogensen, G., Fonden, R., Matto, J. and MattiliaSandholm, T. 2000. Probiotic bacteria: Safety functional and technological properties. Journal of Biotechnology, 84(3): 197215.

Shah, N.P. 2001. Functional Foods from Probiotics and Prebiotics. Food Technology, 55(11): 46-53.

Sripriya G., Chandrasekharan K., Murty V.S. and Chandra T.S. 1996. ESR spectroscopic studies on free radical quenching action of finger millet (Eleusine coracana). Food Chemistry, 57(4): 537-540.

Steinkraus, K.H. 1998. Bio-enrichment: production of vitamins in fermented foods. J.B. Wood (Ed.). In: 'Microbiology of fermented foods'. London: Blackie Academic and Professional, pp. 603-619.

Steinkraus, K.H., Ayres, R., Olek, A. and Farr, D. 1993. Biochemistry of Saccharomyces. K.H. Steinkraus (Ed.). In: 'Handbook of indigenous fermented foods'. New York: Marcel Dekker, pp. 517-519.

Stott, H.A., Smith, H. and Rosen, G.D. 1963. Microbiological evaluation of protein quality with Tetrahymena pyriformis, W.3. A simplified assay procedure. British Journal of Nutrition, 17: 227.

Sultan Arslan-Tontul and Mustafa Erbas. 2020. Co-Culture Probiotic Fermentation of Protein-Enriched Cereal Medium (Boza), Journal of the American College of Nutrition, 39(1): 72-81.

Svensson, U. 1999. Industrial perspectives. In: Tannock, G. W. (Ed). Probiotics: A Critical Review. Horozon Scientific Press, Wymondham, pp. 57-64.

Teniola, O.D. and Odunfa, S.A. 2001. The effects of processing methods on the levels of lysine, methionine and the general acceptability of ogi processed using starter cultures. International Journal of Food Microbiology, 63(1-2): 1-9.

Tongnual, P. and Fields, M.L. 1979. Fermentation and relative nutritive of rice meal and chips. Journal of Food Science, 44(6): 1784-1785.

Toufeili, I., Olabi, A., Shadarevian, S., Abi Antoun, M., Zurayk, R. and Baalbaki, I. 1997. Relationships of selected wheat parameters to bulghul-making quality. Journal of Food Quality, 20(3): 211-224.

Wacher, C., Canas, A., Barzana, E., Lappe, P., Ulloa, M. and Owens, J.D. 2000. Microbiology of Indian and Mestizo pozol fermentation. Food Microbiology, 17(3): 251-6.

Wang H.L., Ruttle D.I. and Hesseltine C.W. 1968. Protein quality of wheat and soybeans after Rhizopus oligosporus fermentation. Journal of Nutrition, 96: 109-114.

Wang, Y.D. and Fields, M.L. 1978. Feasibility of home fermentation to improve the amino acid balance of corn meal. Journal of Food Science, 43(4): 1140.

Wongkhalaung, C. and Boonyaratanakornkit, M. 2000. Development of a yoghurt-type product from saccharified rice. Kasetsart Journal, 34: 107-116.

Zarate, G., Chaia, A.P., Gonzalez, S. and Oliver, G. 2000. Viability and B-galactosidase activity of dairy Propionibacteria subjected to digestion by artificial gastric and intestinal fluids. Journal of Food Protection, 63(9): 12141221.

Zegeye, A. 1997. Acceptability of injera with stewed chicken. Food Quality and Preference, 8(4): 293-295. 